Review

\title{
Formulation and Nanotechnology-Based Approaches for Solubility and Bioavailability Enhancement of Zerumbone
}

\author{
Siddharth S. Kesharwani ${ }^{1, *}$ and G. Jayarama Bhat ${ }^{2}$ \\ 1 College of Pharmacy, Roseman University of Health Sciences, South Jordan, UT 84096, USA \\ 2 Department of Pharmaceutical Sciences, College of Pharmacy and Allied Health Professions, \\ South Dakota State University, Brookings, SD 57007, USA; jayarama.gunaje@sdstate.edu \\ * Correspondence: skesharwani@roseman.edu; Tel.: +1-801-878-1101
}

Received: 14 September 2020; Accepted: 21 October 2020; Published: 23 October 2020

\begin{abstract}
About 40-70\% of drug molecules in the clinical development pipeline suffer from one of either low aqueous solubility, poor absorption, or extremely low bioavailability. Approximately 75\% of the world population relies on traditional therapies and therefore there has been a growing interest in the utilization of natural compounds. Zerumbone is one such natural compound, classified as a sesquiterpenoid that is extracted from the essential volatile oils of rhizomes from Zingiber zerumbet. It possesses strong antitumor, antioxidant, antimicrobial, and anti-inflammatory activity. However, despite promising preclinical studies demonstrating the therapeutic utility of zerumbone, its clinical development has been limited due to its low aqueous solubility, poor absorption, or associated low bioavailability. Multiple reviews demonstrating the pharmacological effects of zerumbone for various diseases have been published. However, to our knowledge, no review demonstrates the various formulation strategies developed to overcome the biopharmaceutical challenges of zerumbone. The purpose of this review is to provide a comprehensive perspective on zerumbone as a molecule for formulation development. A section related to pharmacokinetics, toxicity, and patents of zerumbone is included. This review provides the importance of developing novel formulations of zerumbone to overcome its biopharmaceutical challenges thereby advance its potential in the treatment of various diseases.
\end{abstract}

Keywords: zerumbone; natural products; formulation development; drug delivery systems; pharmacological effects of zerumbone; and molecular targets of zerumbone

\section{Introduction}

With the development of novel drug discovery and development methodologies, there has been an increase in the number of new drug candidates in clinical development [1]. It estimated that $40-70 \%$ of compounds in clinical drug development suffer from low oral bioavailability due to poor aqueous solubility and absorption [2,3]. Drug solubility and permeability are the two fundamental parameters that control the rate and extent of drug absorption. The preclinical and clinical assessment of new drug candidates is hampered because of these challenges mentioned above [4]. Poorly soluble and absorbable drugs pose a significant challenge to the formulation scientists to develop a suitable dosage form that can enhance their solubility and bioavailability [5-8]. The solubility and bioavailability of a drug can be improved through multiple approaches [9] such as chemical modification, salt formation, amorphization, particle size reduction [10], or through different formulation development strategies [11] such as solid dispersions [12], molecular complexation [13-15], lipid-based formulations [16-19], micelles [20,21], and nanoparticles [22]. 
About $70-80 \%$ of the world population relies on traditional therapies, most commonly involving natural compounds $[23,24]$. In the recent years, there has been considerable attention on natural compounds which is primarily based on the premise that these compounds can promote health and alleviate diseases $[23,25]$. Approximately $20-30 \%$ of the modern drugs that are prescribed worldwide are of plant-origin. Most well-known natural compounds are polyphenols, flavonoids, and terpenes [26]. Zerumbone is one such natural compound, classified as a sesquiterpenoid that is extracted from the essential volatile oil of rhizomes from wild ginger, Zingiber zerumbet [27-38]. Zerumbone has been shown to possess strong antitumor [27,30,39], antioxidant [40], antimicrobial [41], anti-nociceptive [42], hepatoprotective [43], immunomodulatory [44], anti-inflammatory [33,45,46], and gastro-protective [40] activity. However, despite promising in-vitro and in-vivo studies demonstrating the therapeutic utility of zerumbone, its preclinical and clinical development has been limited due to its poor water solubility, poor absorption, or low bioavailability, limiting its targeting into various tissues and organs of interest. Hence, to advance the therapeutic potential in various diseases and overcome the biopharmaceutical challenges of zerumbone, it is essential to develop advanced formulation and nanotechnology-based approaches $[28,35-37,47,48]$.

Multiple reviews demonstrate the beneficial pharmacological effects of zerumbone for various diseases such as different types of cancer, wound healing, obesity, inflammatory bowel diseases [27-38,49]. However, to our knowledge, no review demonstrates the various formulation strategies developed to overcome the biopharmaceutical challenges related to zerumbone. The purpose of this review is to provide a comprehensive perspective on zerumbone as a candidate molecule for formulation development. The source, physicochemical properties, structure, and molecular targets of zerumbone are covered in brief details. Various formulation development strategies to overcome the biopharmaceutical challenges have been discussed in sufficient details. We have also reviewed studies related to pharmacokinetics, toxicity, and patents of zerumbone. We believe that this review will provide the importance of developing novel formulations of zerumbone to overcome its biopharmaceutical challenges and to advance its potential as a therapeutic agent in the treatment of various diseases.

\section{Source, Chemistry, Physicochemical Properties, and Pharmacological Effects of Zerumbone}

Zerumbone (2E, 6E, 10E)-2,6,9,9-tetramethylcycloundeca-2,6,10-trien-1-one is a natural monocyclic eleven membered sesquiterpene (three isoprene units) isolated from the rhizomes of the wild ginger Zingiber zerumbet [50,51]. Zerumbone is isolated from Zingiberaceae species, especially Zingiber and Curcuma species. It contains $\alpha, \beta$-carbonyl-based moiety with three double bonds [52-55]. Research from studies has shown that $12-73 \%$ of Zerumbone in Zingiber zerumbet is in the rhizome oils [56,57]. Zerumbone is also known as a pinecone, asian, wild, or shampoo ginger. The molecular formula of zerumbone is $\mathrm{C}_{15} \mathrm{H}_{22} \mathrm{O}$ [33]. It is completely soluble in dimethyl sulfoxide (DMSO) and ethanol but has extremely poor solubility in water $\left(\sim 1-1.5 \mathrm{mg} / \mathrm{L}\right.$ at $\left.25^{\circ} \mathrm{C}\right)[34,58]$. Zerumbone is highly lipophilic and the poor water solubility contributes to poor absorption, low oral bioavailability, and limited targeting to tissues and organs of interest $[28,35-37,47,48]$. The chemical structure and other physicochemical characteristics of zerumbone are presented in Figure 1 and Table 1, respectively.

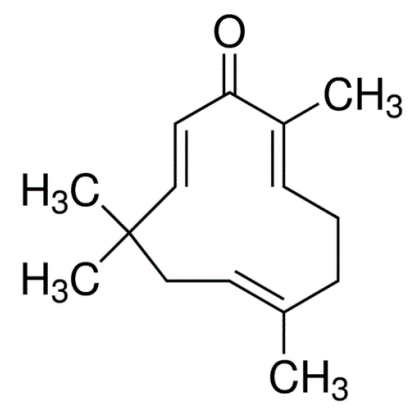

Figure 1. Chemical structure of zerumbone $[29,56]$. 
Table 1. Physicochemical characteristics of zerumbone [56].

\begin{tabular}{|c|c|}
\hline Characteristics & Description \\
\hline Occurrence & Zingiber species \\
\hline Chemical class & Sesquiterpene \\
\hline IUPAC name & $(2 \mathrm{E}, 6 \mathrm{E}, 10 \mathrm{E})-2,6,9,9$-tetramethylcycloundeca-2,6,10-trien-1-one \\
\hline Molecular formula & $\mathrm{C}_{15} \mathrm{H}_{22} \mathrm{O}$ \\
\hline Molecular weight & $218.3 \mathrm{~g} / \mathrm{mol}$ \\
\hline Lop P & 3.9 \\
\hline Chemical structure & $\begin{array}{c}\text { Three-double bond (two conjugated and one isolated), } \alpha, \beta \text {-unsaturated } \\
\text { carbonyl group, and a double conjugated carbonyl group in an 11-membered } \\
\text { ring structure }\end{array}$ \\
\hline Flashing point & $272^{\circ} \mathrm{F}$ \\
\hline Boiling point & $321-322{ }^{\circ} \mathrm{C}$ at $760 \mathrm{mmHg}$ \\
\hline Melting point & $65.3^{\circ} \mathrm{C}$ \\
\hline Appearance & solid white crystals or powder \\
\hline Stability & Stable for at least 2 years when stored at $-20{ }^{\circ} \mathrm{C}$ \\
\hline Solubility & $\begin{array}{l}\text { Freely soluble in organic solvents such as ethanol and dimethyl sulfoxide } \\
\text { (DMSO)Solubility in water } \sim 1-1.5 \mathrm{mg} / \mathrm{L} \text { at } 25^{\circ} \mathrm{C}\end{array}$ \\
\hline
\end{tabular}

Zerumbone is known to exhibit numerous biological and pharmacological effects (Figure 2) such as antitumor, antioxidant, antimicrobial, anti-nociceptive, hepatoprotective, immunomodulatory, anti-inflammatory, gastro-protective, and antiproliferative through modulation of various molecular targets (Figure 3) and signaling mechanisms. Multiple reviews and extensive amount of studies have been performed detailing the molecular targets of zerumbone for various chronic diseases and have been reviewed in references elsewhere in great detail $[27,28,30-39,43,45-47,49,56,59,60]$.

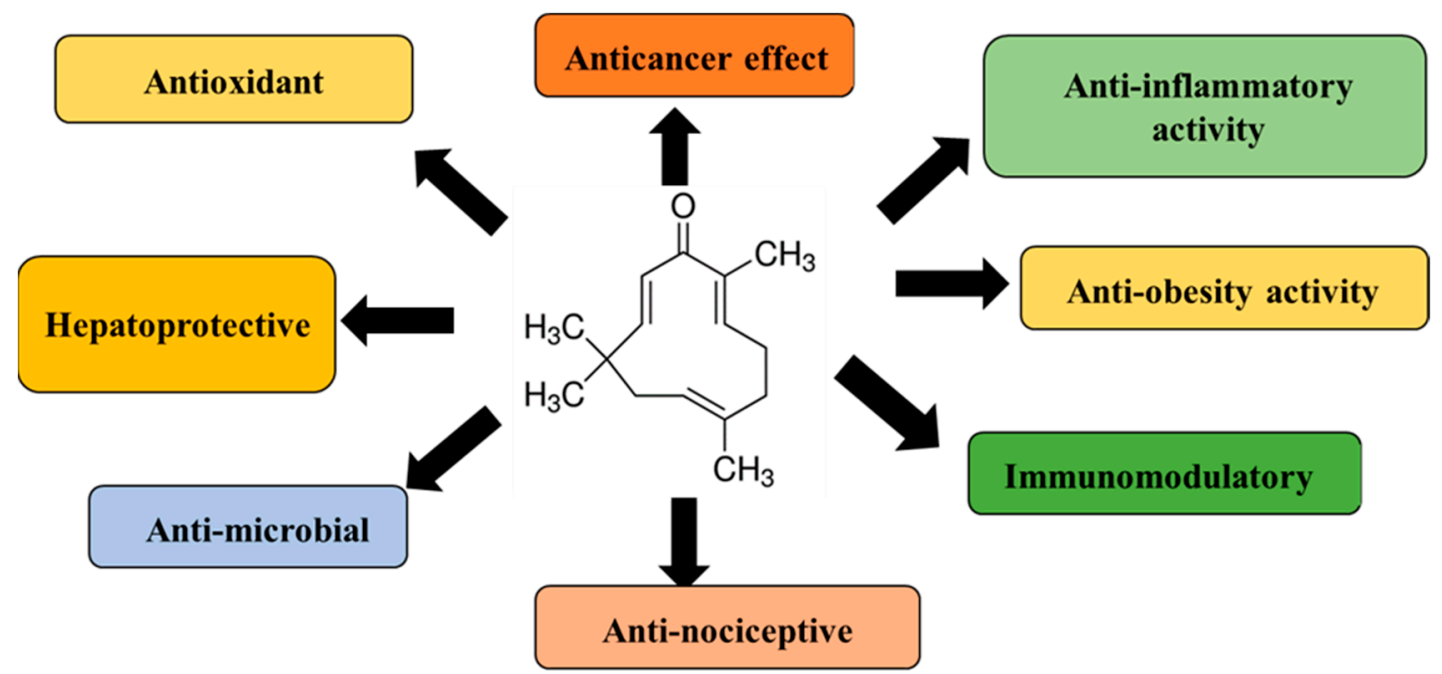

Figure 2. Summary of pharmacological effects of zerumbone. 


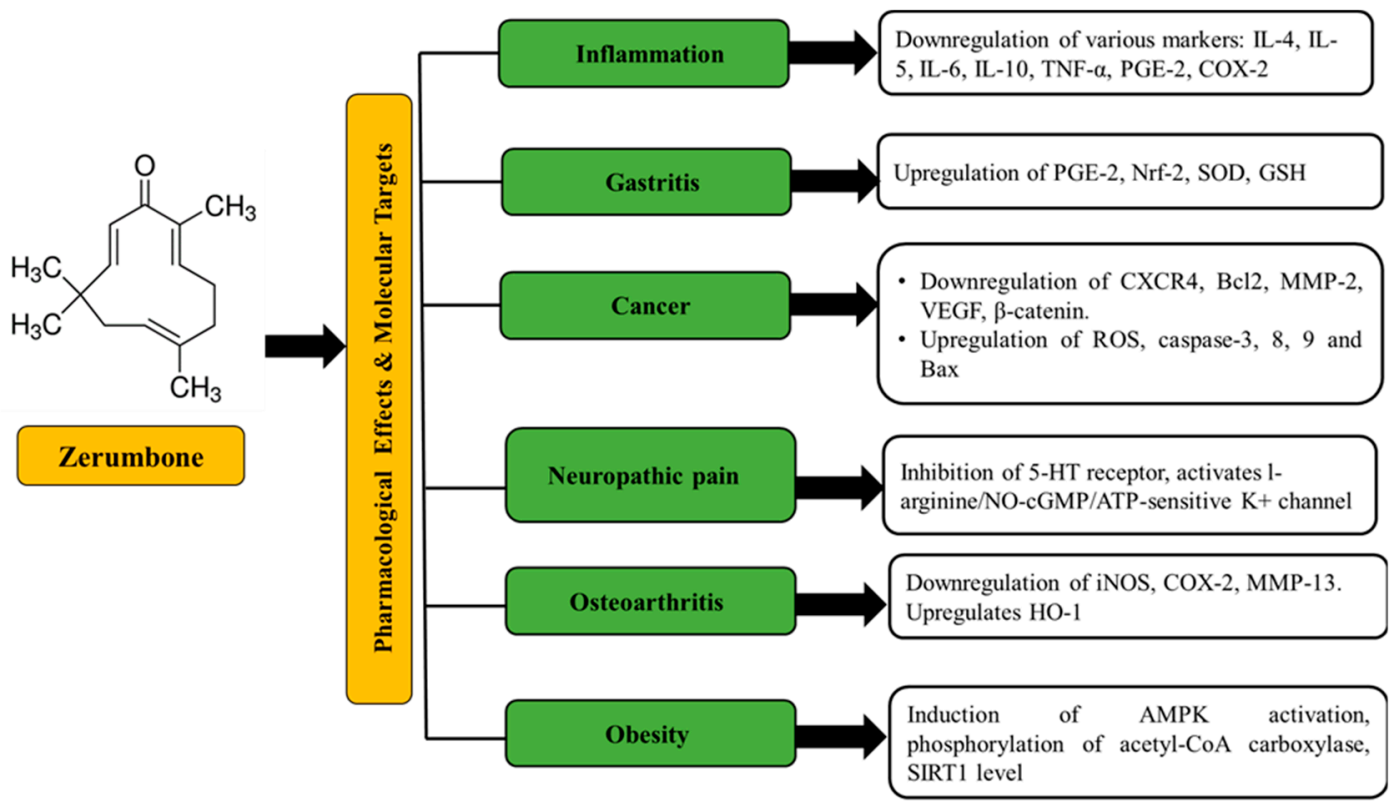

Figure 3. Molecular targets of zerumbone for various diseases [49].

\section{Formulation Development and Drug Delivery Strategies of Zerumbone}

With the advancement of combinatorial chemistry, high-throughput screening and cell-based assays, new chemical entities (NCEs) are being developed. However, nearly $40 \%$ of the drugs currently in the clinical drug development pipeline and $~ 75 \%$ of therapeutic molecules in the market suffer from low aqueous solubility and poor oral bioavailability. These biopharmaceutical limitations affect the discovery stage studies and thereby lead to a significant delay in the development of new drugs $[3,4,9,12]$. According to the biopharmaceutical classification system (BCS), the drug dissolution profile and solubility are major factors that affect gastrointestinal permeability, bioavailability, and clinical response. Drugs with poor aqueous solubility suffer from low bioavailability and limited transport after oral administration [1-3]. Thus, it is imperative to develop strategies to overcome the solubility and bioavailability concerns of poorly soluble compounds. To overcome these biopharmaceutical challenges, numerous strategies have been applied, such as chemical/structural modification, chelation, bio-conjugation, using a water-soluble polymer, inclusion complex formation, amorphous solid dispersions, reduction of particle size, lipid-based technology, nanocrystal technology, and nanoparticulate technology.

Zerumbone possesses numerous beneficial pharmacological activities as outlined above [49]. Despite having promising pharmacological activities, the preclinical and clinical utility of zerumbone has been limited due to its low aqueous solubility and poor oral bioavailability. The subsequent section and the Table 2 provides a concise review of the formulation development strategies that have been employed for the delivery of zerumbone. It provides details about the type of formulation developed, components of the delivery system, method of preparation, purpose, therapeutic indication, and the major results. The purpose is to provide researchers with the idea of the studies that have been published and the major area to concentrate upon when developing novel drug delivery strategies for zerumbone with the overall goal to enhance its therapeutic potential. Thee major approaches have been explored and they include: (i) nanostructured lipid carriers, (ii) inclusion complexes of cyclodextrins, and (iii) nanosuspensions (Figure 4). The majority of the studies demonstrate an enhancement of in-vitro aqueous solubility, stability, and in-vitro cytotoxicity of zerumbone-based formulations in cancer cell lines. However, none of these drug delivery strategies study the in-vivo pharmacokinetics or evaluate the in-vivo pharmacological activity of zerumbone. 
Table 2. Formulation development strategies and delivery systems of zerumbone.

\begin{tabular}{|c|c|c|c|c|c|c|}
\hline $\mathrm{Nr}$ & $\begin{array}{l}\text { Formulation } \\
\text { Strategy }\end{array}$ & $\begin{array}{l}\text { Method of } \\
\text { Preparation }\end{array}$ & Components of Delivery System & $\begin{array}{l}\text { Therapeutic } \\
\text { Indication }\end{array}$ & Purpose & Major Results/Conclusions \\
\hline 1 & $\begin{array}{l}\text { Nanostructured lipid } \\
\text { carriers [36] }\end{array}$ & $\begin{array}{l}\text { Hot, high-pressure } \\
\text { homogenization }\end{array}$ & $\begin{array}{c}\text { Lipid dispersion: hydrogenated palm } \\
\text { oil, olive oil, and lipoid S100 } \\
\text { Aqueous dispersion: } \\
\text { Sorbitol, Tween-80 and thiomersal }\end{array}$ & Leukemia & Treatment of leukemia & $\begin{array}{l}\text { The zerumbone-loaded nanocarriers } \\
\text { depict sustained release characteristics } \\
\text { and high cytotoxicity in human T-cell } \\
\text { acute lymphocytic leukemia. }\end{array}$ \\
\hline 2 & $\begin{array}{l}\text { Nanostructured lipid } \\
\text { carriers [37] }\end{array}$ & $\begin{array}{l}\text { Hot, high-pressure } \\
\text { homogenization }\end{array}$ & $\begin{array}{l}\text { hydrogenated palm } \\
\text { oil, distilled water, olive oil, lipoid- } \\
\text { S 100, lecithin, thimerosal, and sorbitol }\end{array}$ & $\begin{array}{l}\text { Antileukemic effect } \\
\text { and acute toxicity }\end{array}$ & $\begin{array}{l}\text { Acute toxicity of } \\
\text { zerumbone and } \\
\text { zerumbone-loaded } \\
\text { nanocarriers via the oral } \\
\text { route of administration }\end{array}$ & $\begin{array}{c}\text { Both zerumbone and } \\
\text { zerumbone-loaded lipid nanocarriers } \\
\text { at acute doses do not induce } \\
\text { behavioral alterations, toxicological } \\
\text { signs, or adverse effects. }\end{array}$ \\
\hline 3 & $\begin{array}{l}\text { Nanostructured lipid } \\
\text { nanocarriers [35] }\end{array}$ & $\begin{array}{l}\text { Hot, high-pressure } \\
\text { homogenization }\end{array}$ & $\begin{array}{c}\text { Lipid dispersion: hydrogenated palm } \\
\text { oil, olive oil, and lipoid S100 } \\
\text { Aqueous dispersion: } \\
\text { Sorbitol, Tween-80 and thiomersal }\end{array}$ & $\begin{array}{c}\text { Colorectal } \\
\text { adenocarcinoma }\end{array}$ & $\begin{array}{c}\text { Increase the potency and } \\
\text { efficacy of } \\
\text { zerumbone-loaded lipid } \\
\text { nanocarriers }\end{array}$ & $\begin{array}{l}\text { Zerumbone lipid nanocarriers depict } \\
\text { slow release of the drug without } \\
\text { altering the anti-cancer effect. }\end{array}$ \\
\hline 4 & $\begin{array}{l}\text { Nanostructured lipid } \\
\text { nanocarriers [28] }\end{array}$ & $\begin{array}{l}\text { Hot, high-pressure } \\
\text { homogenization }\end{array}$ & $\begin{array}{c}\text { Lipid dispersion: hydrogenated palm } \\
\text { oil, olive oil, and lipoid S100 } \\
\text { Aqueous dispersion: } \\
\text { Sorbitol, Tween- } 80 \text { and thiomersal }\end{array}$ & $\begin{array}{l}\text { Canine mammary } \\
\text { gland tumor }\end{array}$ & $\begin{array}{l}\text { Antiproliferative effect and } \\
\text { the mode of cell death on } \\
\text { canine mammary gland } \\
\text { tumor adenocarcinoma }\end{array}$ & $\begin{array}{l}\text { Effective in inhibiting the proliferation } \\
\text { and inducing apoptosis on the canine } \\
\text { mammary gland tumor cells. } \\
\text { Inhibition of Bcl-2 and activation of } \\
\text { pro-apoptotic Bax gene expressions } \\
\text { and activation of caspases of the } \\
\text { intrinsic and extrinsic apoptosis } \\
\text { pathways were reasons for the effect. }\end{array}$ \\
\hline 5 & $\begin{array}{l}\text { Inclusion complexes } \\
{[60]}\end{array}$ & $\begin{array}{l}\text { Inclusion complex } \\
\text { through freeze-drying }\end{array}$ & Hydroxypropyl- $\beta$-cyclodextrin & Anticancer drug effect & $\begin{array}{l}\text { Enhancement of solubility } \\
\text { of zerumbone }\end{array}$ & $\begin{array}{l}\text { Important modifications in the } \\
\text { solubility and stability of zerumbone }\end{array}$ \\
\hline 6 & Nanosuspensions [48] & $\begin{array}{l}\text { High-pressure } \\
\text { homogenization }\end{array}$ & $\begin{array}{l}\text { Hydroxypropyl methylcellulose } \\
\text { (HPMC) and sodium dodecyl sulfate } \\
\text { (SDS) }\end{array}$ & Not applicable & $\begin{array}{l}\text { Improve solubility and } \\
\text { dissolution characteristic's }\end{array}$ & $\begin{array}{l}\text { Enhanced dissolution and saturation } \\
\text { solubility of zerumbone. }\end{array}$ \\
\hline 7 & $\begin{array}{l}\text { Nanostructured lipid } \\
\quad \text { carrier gel [47] }\end{array}$ & $\begin{array}{l}\text { Hot, high-pressure } \\
\text { homogenization }\end{array}$ & $\begin{array}{l}\text { Carbopol } 980 \text { used to } \\
\text { prepare the nanostructured lipid } \\
\text { carrier gel }\end{array}$ & Wound healing & Anti-inflammatory activity & $\begin{array}{l}\text { The gel decreased inflammatory cell } \\
\text { infiltration and degeneration and } \\
\text { increased granulation in healing } \\
\text { wound tissues. There was an increase } \\
\text { of anti-inflammatory IL-10, decreased } \\
\text { the pro-inflammatory TNF- } \alpha \text {, IL-6 } \\
\text { concentrations, and downregulated } \\
\text { cyclooxygenase-2 } \\
\text { gene expression. }\end{array}$ \\
\hline
\end{tabular}




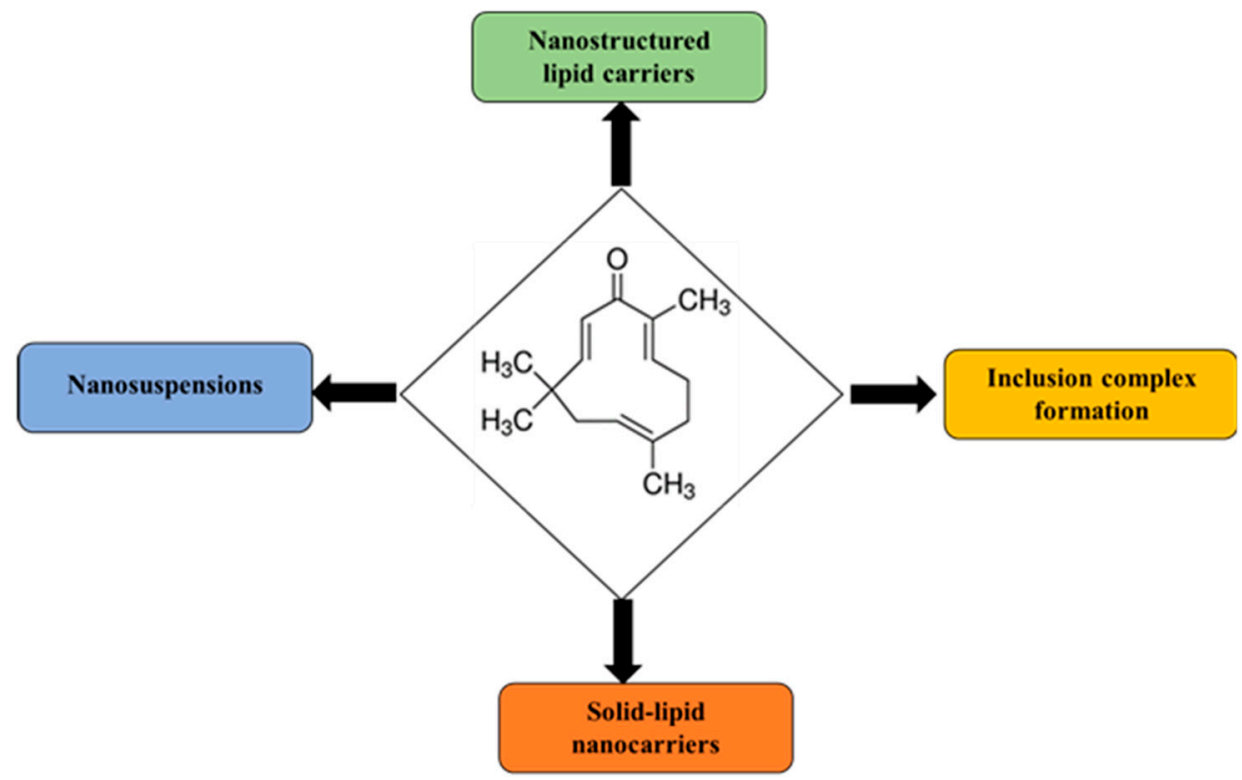

Figure 4. Formulation strategies employed to improve the solubility and bioavailability of zerumbone.

\subsection{Nanostructured Lipid Carriers}

Lipid nanocarriers, include solid lipid nanoparticles (SLNs), and nanostructured lipid carriers (NLCs), are recognized as suitable carriers for drug delivery to enhance the solubility of poorly water-soluble compounds [19]. SLNs are the first type of lipid carrier to consist of solid and biocompatible matrixes [61]. Nanostructure lipid carriers contain both solid and liquid lipids. Specifically, the hybrid lipid scheme has been studied to ensure excellent biological applicability, controlled drug release, and possibilities of large industrial development in comparison with SLNs. NLCs are a modified form of SLNs which provide enhanced drug stability, controlled and site-specific drug release, enhanced drug loading capacity, and prevention of drug expulsion during storage $[17,18,62]$. The NLCs surface can be modified and loaded with hydrophobic or hydrophilic drugs. The carrier material is biodegradable and safe when administered in-vivo with enhanced physical and chemical stability $[16,63]$.

Multiple zerumbone-loaded nanostructured lipid carriers have been formulated. Rahman et al. developed nanostructured lipid nanocarriers of zerumbone using hot, high-pressure homogenization technique and evaluated the antileukemic effect. Through a thorough physio-chemical and in-vitro biological characterization, the authors report stability, sustained release characteristics, and high cytotoxicity of zerumbone-loaded lipid nanocarriers in human lymphocytic leukemia cells as compared to zerumbone [36]. In another study, Rahman et al. extended the previous study to evaluate the acute toxicity of zerumbone-loaded nanocarriers in BALB/c mice after oral administration. The author's report $50 \%$ lethal dose $\left(\mathrm{LD}_{50}\right)$ of zerumbone-loaded nanocarriers to be higher than $200 \mathrm{mg} / \mathrm{kg}$, and that this is safe via the oral route of administration [37,56]. In separate studies by Nathaniel et al. [35] and Foong et al. [28] evaluated the ability of zerumbone-loaded nanocarriers to induce apoptosis in human colorectal cancer cell lines and canine mammary adenocarcinoma cells (Table 2).

\subsection{Inclusion Complexes of Cyclodextrins}

Cyclodextrins are cyclic oligosaccharides constituted by six ( $\alpha$-cyclodextrin), seven ( $\beta$-cyclodextrin), and eight $(\gamma$-cyclodextrin) glucopyranose units linked by $\alpha-(1,4)$ bonds. Hydroxypropyl- $\beta$-cyclodextrin (HP- $\beta-C D)$ is cyclodextrin derivative that has been studied widely in the field for drug encapsulation because of its ability to form inclusion complexes and the ability to increase aqueous solubility [64-68]. In a study by Eid et al., the authors evaluated the inclusion complex formation of HP- $\beta-C D$ and zerumbone in an aqueous medium to enhance the aqueous solubility of zerumbone. Through a combination of multiple physicochemical characterization methods, the authors report the formation 
of inclusion complexes of zerumbone and HP- $\beta-\mathrm{CD}$ leading to an increase in solubility, stability, and bioavailability. This study further enhanced the potential of zerumbone as a therapeutic molecule via oral administration [60].

\subsection{Nanosuspensions}

Formulating nanosuspensions is one of the strategies to improve the oral bioavailability of poorly soluble drugs. Since the introduction of the first nanosuspension in 1992, the $1^{\text {st }}$ product to be approved by the Food and Drug Administration (US-FDA) in 2000 was Rapamune ${ }^{\circledR}$, an immunosuppressive agent. Currently, there are more than $15+$ products in the market, which are growing fast, due to the potential of this technology. The size of the nanosuspensions improves the saturation solubility and dissolution rate of the drug, thereby leading to an increase in oral bioavailability. In addition, nanosuspensions also provide enhanced stability, reduced toxicity, and increased pharmacological activity [69-73]. With the purpose to increase the aqueous solubility of zerumbone, Shadab et al. formulated nanosuspensions of zerumbone using high-pressure homogenization (HPH) with sodium dodecyl sulfate (SDS) and hydroxypropyl methylcellulose (HPMC) as stabilizers. The optimized formulation was characterized by various physicochemical properties. The authors report an increase in solubility, stability, and dissolution profile of zerumbone nanosuspension as compared to zerumbone alone. The results from this study provide evidence of the potential of nanosuspension technology to enhance the therapeutic potential of zerumbone in the future and warrant further in-vivo evaluation [48].

\section{Pharmacokinetics and Toxicity of Zerumbone and Zerumbone Formulations}

Zerumbone has been found to possess multiple beneficial pharmacological effects as outlined above. Despite the plethora of studies demonstrating the activities of zerumbone, there exists only limited evidence regarding the pharmacokinetics and toxicity of zerumbone $[31,32,37,59,60]$. Based on the potential therapeutic utility of zerumbone, it is expected that zerumbone would be used over a prolonged time and it is essential to evaluate the pharmacokinetics and toxic effects of the compound in both acute and chronic settings [74]. The subsequent section reports the limited preliminary investigations regarding the in-vitro and in-vivo toxic effects of zerumbone. Most of these studies are performed from three perspectives, mainly acute/chronic toxicity, genotoxicity, and cytotoxicity examinations. More preclinical and clinical toxicity studies are warranted to establish zerumbone as a therapeutic drug for the prevention and treatment of various chronic diseases. Furthermore, it is also imperative to study the pharmacokinetics of zerumbone and zerumbone formulations to aid in the development of this compound and overcome the solubility and associated low bioavailability concerns. All the relevant studies performed so far have been briefly explained and summarized in the subsequent section and Table 3 .

Table 3. Toxicity studies with zerumbone and zerumbone-based formulations.

\begin{tabular}{|c|c|c|c|}
\hline Type of Study & Subjects & Dose & Key Results \\
\hline Acute toxicity [31] & Sprague Dawley rats & $100-3000 \mathrm{mg} / \mathrm{kg}$ & $\begin{array}{l}\text { The results from this study showed that single injected } \\
\text { doses of zerumbone at } 100-200 \mathrm{mg} / \mathrm{kg} \text { had no toxic } \\
\text { effects on the renal and liver tissues of rats. The death } \\
\text { of all experimental animals was reported at high doses } \\
\text { of } 2500 \text { and } 3000 \mathrm{mg} / \mathrm{kg} \text {, and } 20 \text { and } 40 \% \text { of animals } \\
\text { died at doses of } 1500 \text { and } 2000 \mathrm{mg} / \mathrm{kg} \text { respectively. } \\
\text { In addition, a dose of } 500 \mathrm{mg} / \mathrm{kg} \text { induced } \\
\text { nephrocellular and hepatocellular damage leading to } \\
\text { renal and hepatic failure. The } \mathrm{LD}_{50} \text { value was } \\
1.84 \mathrm{~g} / \mathrm{kg} \text { when injected intraperitoneally. }\end{array}$ \\
\hline Genotoxicity [59] & $\begin{array}{l}\text { Chinese hamster ovary } \\
(\mathrm{CHO}) \text { cell lines }\end{array}$ & 2.5 to $80 \mu \mathrm{M} / \mathrm{mL}$ & $\begin{array}{c}\text { The results from this study reported that zerumbone at } \\
\text { high concentrations had a genotoxic and cytotoxic } \\
\text { effect on CHO cells. However, it failed to induced } \\
\text { mutagenic effects on Salmonella } \\
\text { Typhimurium strain TA100 }\end{array}$ \\
\hline
\end{tabular}


Rahman et al. studied the acute toxicity of zerumbone and zerumbone-loaded nanocarriers on the BALB/c mice model for 14 days via oral route of administration. They evaluated animals for clinical and behavioral abnormalities, toxicological symptoms, feed consumption, gross appearance, serum biochemical parameters, total hemogram, and bone marrow stem cells. The authors report that all the treated mice and their tissues (liver, kidney, spleen, lung, heart, and brain tissues), serum biochemical parameters, total hemogram, and bone marrow were normal. In addition, the study reports that 100 and $200 \mathrm{mg} / \mathrm{kg}$ zerumbone-loaded nanocarriers did not show any signs of toxicity or mortality in BALB/c mice. Overall, it was found that both zerumbone and zerumbone-loaded lipid nanocarriers are potentially safe to administer via the oral route [37].

Jin et al. evaluated the single and repeat-dose toxicity of zerumbone in mice. The authors evaluated body and organ weight, food and water consumption, hematology, and serum biochemistry, as well as histology effects. The study reports that there were no significant differences in the general condition, serum biochemistry, growth, organ weights, hematology, or histopathological analysis in the repeat dose toxicity. Overall, it can be concluded that zerumbone is safe to administer. Zubairi et al. studied the in-vitro and in-vivo genotoxic effects of zerumbone and reported that higher doses $(1000 \mathrm{mg} / \mathrm{kg}$ body weight) of zerumbone could potentially be genotoxic and cytotoxic [32].

Ibrahim et al. evaluated the acute toxicity and the effect of a single dose of zerumbone on the kidney and liver functions in Sprague Dawley rats. The overall goal was to determine the median lethal dose $\left(\mathrm{LD}_{50}\right)$ of zerumbone and the effect of three different doses of zerumbone below the $\mathrm{LD}_{50}$ on various parameters such as blood biochemistry, hepatic, renal histopathologies, lipid peroxidation in rats. The results from this study report the $\mathrm{LD}_{50}$ of zerumbone to be $1.84 \mathrm{gm} / \mathrm{kg}$. It was also found that zerumbone at 100-200 mg/kg had no toxic effects on the rats under the study. However, doses of $500 \mathrm{mg} / \mathrm{kg}$ of zerumbone induced hepatocellular and nephrocellular damage leading to kidney and liver failure [31].

Eid et al. studied the pharmacokinetics of zerumbone-based inclusion complexes of hydroxypropyl- $\beta$ cyclodextrin (HP- $\beta-\mathrm{CD})$ via intravenous and intraperitoneal administration. The authors report various pharmacokinetic parameters of zerumbone and zerumbone-based inclusion complexes of cyclodextrin. It was found that the HP $\beta C D$ had a negligible effect on the pharmacokinetic parameters of zerumbone [60].

\section{Patents Related to Zerumbone and Zerumbone Formulations}

An extensive search for zerumbone and its formulations was conducted using Google Patents (patents.google.com), USPTO Patent full-text search (www.uspto.gov), WIPO IP Portal's Patent scope (https://patentscope.wipo.int/), and Espacenet (worldwide.espacenet.com/patent/). After a careful review, it was found that only a few patents were directly related to zerumbone and its formulations. Table 4 provides the details of the patented systems and their clinical application. From Table 4 , it is clear that very few patents exist in the area of formulations of zerumbone and there exists an enormous opportunity for formulation scientists to develop novel formulations. In addition, most of these patented systems are related to a particular formulation type with utility for a specific disease thereby being very narrow in its claims and utility. This further provides the opportunity to expand the scope and develop novel technologies related to zerumbone with broader applicability. 
Table 4. Patented systems related to zerumbone and zerumbone-based formulations.

\begin{tabular}{|c|c|c|c|}
\hline Year & Patented System & $\begin{array}{l}\text { Patent/Publication } \\
\text { Number }\end{array}$ & Clinical Application \\
\hline 2019 & $\begin{array}{l}\text { A gel containing zerumbone from } \\
\text { bitter ginger for curative treatment of } \\
\text { diabetic ulcers }\end{array}$ & WO2019173890A1 & $\begin{array}{l}\text { A dermatological pharmaceutical } \\
\text { composition in the form of a gel for } \\
\text { topical use containing zerumbone. }\end{array}$ \\
\hline 2019 & Method for treating an allergic disease & $\begin{array}{l}\text { United States Patent } \\
10688078\end{array}$ & $\begin{array}{l}\text { The invention relates to the use of } \\
\text { zerumbone for treating an } \\
\text { allergic disease. }\end{array}$ \\
\hline 2018 & $\begin{array}{l}\text { New use of zerumbone and } \\
\text { compositions comprising zerumbone }\end{array}$ & EP2802310B1 & $\begin{array}{l}\text { The topical use of zerumbone for the } \\
\text { treatment of the deficiencies of the } \\
\text { capillary network of the skin. It also } \\
\text { helps to treat micro-subcutaneous } \\
\text { edemas, including bags and/or dark } \\
\text { circles under the eyes. }\end{array}$ \\
\hline 2014 & A composition for treating leukemia & WO2014123406A1 & $\begin{array}{l}\text { The composition comprises an } \\
\text { effective amount of zerumbone and a } \\
\text { pharmaceutically acceptable } \\
\text { nanostructured lipid carrier for } \\
\text { treating leukemia. }\end{array}$ \\
\hline 2013 & $\begin{array}{l}\text { Inclusion complex of zerumbone with } \\
\text { a hydroxypropyl- } \beta \text {-cyclodextrin } \\
(H P-\beta-C D) \text { in aqueous form }\end{array}$ & MY149711A & $\begin{array}{c}\text { The present invention relates to a } \\
\text { novel zerumbone inclusion complex } \\
\text { having improved solubility } \\
\text { properties. }\end{array}$ \\
\hline 2009 & $\begin{array}{l}\text { Immune modulation and anti-allergy } \\
\text { activities of Zingiber zerumbet }\end{array}$ & $\begin{array}{l}\text { United States Patent } \\
7588788\end{array}$ & $\begin{array}{l}\text { The present invention provides for a } \\
\text { method of preparing a nutraceutical } \\
\text { formulation comprising zerumbone, } \\
\text { and the use of this formulation to } \\
\text { regulate the immune system, and } \\
\text { more specifically to prevent or to treat } \\
\text { an allergic disorder. }\end{array}$ \\
\hline
\end{tabular}

\section{Conclusions and Future Outlook}

Drugs with poor solubility suffer from poor oral bioavailability and limited transport after oral administration. Zerumbone possesses numerous beneficial pharmacological activities as outlined above. Despite having promising pharmacological activities, the preclinical and clinical utility of zerumbone has been limited due to its poor aqueous solubility, poor absorption, and low oral bioavailability. The formulation development studies performed are limited to only in-vitro or preliminary in-vivo studies. New formulations and delivery methods are needed to increase the solubility of poorly soluble drugs, including zerumbone. The studies on formulation development are limited to nanostructured lipid carriers, nanosuspensions, gels, and inclusion complex formation with cyclodextrins. To our knowledge, no data have been reported for its pharmacokinetics and pharmacodynamics in large animals and humans. For the successful development of water-soluble and stable formulation, it is important to carry out further investigations using various tests (toxicity, pharmacokinetics, and pharmacological studies) under acute and chronic setting. Furthermore, it is essential to perform a thorough physicochemical and biopharmaceutical characterization to translate the potential of zerumbone as a therapeutic agent. The findings from all the researches reviewed in this paper provides conclusive evidence that zerumbone has a strong potential for formulation development for various diseases. In addition, there is a need to conduct animal studies, pharmacokinetic and pharmacodynamics evaluation, detailed toxicological, and human clinical trials to ascertain the efficacy, usefulness, and safety of zerumbone. 
Author Contributions: S.S.K. and G.J.B. wrote, edited, and revised the manuscript. All authors have read and agreed to the published version of the manuscript.

Funding: This research received no external funding.

Acknowledgments: Siddharth S. Kesharwani would like to acknowledge the College of Pharmacy, Roseman University of Health Sciences, USA for supporting the research and scholarly activities.

Conflicts of Interest: The authors declare no conflict of interest.

\section{References}

1. Dressman, J.; Butler, J.; Hempenstall, J.; Reppas, C. The BCS: Where do we go from here? Pharm. Technol. 2001, 25, 68-77.

2. Ghadi, R.; Dand, N. BCS class IV drugs: Highly notorious candidates for formulation development. J. Control. Release 2017, 248, 71-95. [CrossRef] [PubMed]

3. Lipinski, C.A.; Lombardo, F.; Dominy, B.W.; Feeney, P.J. Experimental and computational approaches to estimate solubility and permeability in drug discovery and development settings. Adv. Drug Deliv. Rev. 1997, 23, 3-25. [CrossRef]

4. Lipinski, C.A. Drug-like properties and the causes of poor solubility and poor permeability. J. Pharmacol. Toxicol. Methods 2000, 44, 235-249. [CrossRef]

5. Gao, L.; Zhang, D.; Chen, M. Drug nanocrystals for the formulation of poorly soluble drugs and its application as a potential drug delivery system. J. Nanopart. Res. 2008, 10, 845-862. [CrossRef]

6. Seenivasan, A.; Panda, T.; Théodore, T. Lovastatin nanoparticle synthesis and characterization for better drug delivery. Open Biotechnol. J. 2011, 5, 28-32. [CrossRef]

7. Souto, E.; Wissing, S.; Barbosa, C.; Müller, R. Development of a controlled release formulation based on SLN and NLC for topical clotrimazole delivery. Int. J. Pharm. 2004, 278, 71-77. [CrossRef]

8. Bartos, C.; Szabó-Révész, P.; Bartos, C.; Katona, G.; Jójárt-Laczkovich, O.; Ambrus, R. The effect of an optimized wet milling technology on the crystallinity, morphology and dissolution properties of micro-and nanonized meloxicam. Molecules 2016, 21, 507. [CrossRef]

9. Savjani, K.T.; Gajjar, A.K.; Savjani, J.K. Drug solubility: Importance and enhancement techniques. Int. Sch. Res. Not. 2012, 2012, 195727. [CrossRef]

10. Merisko-Liversidge, E.; Liversidge, G.G. Nanosizing for oral and parenteral drug delivery: A perspective on formulating poorly-water soluble compounds using wet media milling technology. Adv. Drug Deliv. Rev. 2011, 63, 427-440. [CrossRef]

11. Paulino, A.; Rauber, G.; Campos, C.; Maurício, M.; De Avillez, R.; Capobianco, G.; Cardoso, S.; Cuffini, S. Dissolution enhancement of Deflazacort using hollow crystals prepared by antisolvent crystallization process. Eur. J. Pharm. Sci. 2013, 49, 294-301. [CrossRef] [PubMed]

12. Sareen, S.; Mathew, G.; Joseph, L. Improvement in solubility of poor water-soluble drugs by solid dispersion. Int. J. Pharm. Investig. 2012, 2, 12. [CrossRef] [PubMed]

13. Kumar, S.; Kesharwani, S.S.; Mathur, H.; Tyagi, M.; Bhat, G.J.; Tummala, H. Molecular complexation of curcumin with $\mathrm{pH}$ sensitive cationic copolymer enhances the aqueous solubility, stability and bioavailability of curcumin. Eur. J. Pharm. Sci. 2016, 82, 86-96. [CrossRef] [PubMed]

14. Kesharwani, S.S.; Ahmad, R.; Bakkari, M.A.; Rajput, M.K.; Dachineni, R.; Valiveti, C.K.; Kapur, S.; Bhat, G.J.; Singh, A.B.; Tummala, H. Site-directed non-covalent polymer-drug complexes for inflammatory bowel disease (IBD): Formulation development, characterization and pharmacological evaluation. J. Control. Release 2018, 290, 165-179. [CrossRef]

15. Hassan, M.A.; Suleiman, M.S.; Najib, N.M. Improvement of the in vitro dissolution characteristics of famotidine by inclusion in $\beta$-cyclodextrin. Int. J. Pharm. 1990, 58, 19-24. [CrossRef]

16. Mistry, S.; Patel, P.; Bharadia, P.; Pandya, V.; Modi, D. Novel drug delivery system for lipophilic agents: Solid lipid nanoparticles. J. Pharm. Cosmetol. 2011, 1, 76-89.

17. Müller, R.H.; MaÈder, K.; Gohla, S. Solid lipid nanoparticles (SLN) for controlled drug delivery-a review of the state of the art. Eur. J. Pharm. Biopharm. 2000, 50, 161-177. [CrossRef]

18. Müller, R.H.; Radtke, M.; Wissing, S.A. Solid lipid nanoparticles (SLN) and nanostructured lipid carriers (NLC) in cosmetic and dermatological preparations. Adv. Drug Deliv. Rev. 2002, 54, S131-S155. [CrossRef] 
19. Shaji, J.; Jain, V. Solid lipid nanoparticles: A novel carrier for chemotherapy. Int. J. Pharmacol. Pharm. Sci. 2010, 2, 8-17.

20. Muley, P.; Kumar, S.; El Kourati, F.; Kesharwani, S.S.; Tummala, H. Hydrophobically modified inulin as an amphiphilic carbohydrate polymer for micellar delivery of paclitaxel for intravenous route. Int. J. Pharm. 2016, 500, 32-41. [CrossRef] [PubMed]

21. Kesharwani, S.S.; Dachineni, R.; Bhat, G.J.; Tummala, H. Hydrophobically modified inulin-based micelles: Transport mechanisms and drug delivery applications for breast cancer. J. Drug Deliv. Sci. Technol. 2019, 54, 101254. [CrossRef]

22. Júlio, A.; Lima, S.A.C.; Reis, S.; de Almeida, T.S.; Fonte, P. Development of ionic liquid-polymer nanoparticle hybrid systems for delivery of poorly soluble drugs. J. Drug Deliv. Sci. Technol. 2019, 100915. [CrossRef]

23. Craig, W.J. Health-promoting properties of common herbs. Am. J. Clin. Nutr. 1999, 70, 491s-499s. [CrossRef] [PubMed]

24. Lucas, D.M.; Still, P.C.; Bueno Perez, L.; Grever, M.R.; Douglas Kinghorn, A. Potential of plant-derived natural products in the treatment of leukemia and lymphoma. Curr. Drug Targets 2010, 11, 812-822. [CrossRef] [PubMed]

25. Rates, S.M.K. Plants as source of drugs. Toxicon 2001, 39, 603-613. [CrossRef]

26. Shanmugam, M.K.; Kannaiyan, R.; Sethi, G. Targeting cell signaling and apoptotic pathways by dietary agents: Role in the prevention and treatment of cancer. Nutr. Cancer 2011, 63, 161-173. [CrossRef]

27. Abdul, A.; Al-Zubairi, A.; Tailan, N.; Wahab, S.; Zain, Z.; Ruslay, S.; Syam, M. Anticancer activity of natural compound (Zerumbone) extracted from Zingiber zerumbet in human HeLa cervical cancer cells. Int. J. Pharmacol. 2008, 4, 160-168.

28. Foong, J.N.; Selvarajah, G.T.; Rasedee, A.; Rahman, H.S.; How, C.W.; Beh, C.Y.; Teo, G.Y.; Ku, C.L. Zerumbone-Loaded Nanostructured Lipid Carrier Induces Apoptosis of Canine Mammary Adenocarcinoma Cells. BioMed Res. Int. 2018, 2018. [CrossRef]

29. Girisa, S.; Shabnam, B.; Monisha, J.; Fan, L.; Halim, C.E.; Arfuso, F.; Ahn, K.S.; Sethi, G.; Kunnumakkara, A.B. Potential of zerumbone as an anti-cancer agent. Molecules 2019, 24, 734. [CrossRef]

30. Haque, M.A.; Jantan, I.; Arshad, L.; Bukhari, S.N.A. Exploring the immunomodulatory and anticancer properties of zerumbone. Food Funct. 2017, 8, 3410-3431. [CrossRef]

31. Ibrahim, M.Y.; Abdul, A.; Ibrahim, T.A.T.; Abdelwahab, S.I.; Elhassan, M.M.; Syam, M. Evaluation of acute toxicity and the effect of single injected doses of zerumbone on the kidney and liver functions in Sprague Dawley rats. Afr. J. Biotechnol. 2010, 9, 4442-4450.

32. Jin, Y.B.; Seo, W.-D.; Lee, Y.-J.; Lee, Y.-S.; Lee, H.-J. Toxicological evaluation of zerumbone on antitumor effects in mice. Afr. J. Pharm. Pharmacol. 2013, 7, 466-473. [CrossRef]

33. Murakami, A.; Takahashi, D.; Kinoshita, T.; Koshimizu, K.; Kim, H.W.; Yoshihiro, A.; Nakamura, Y.; Jiwajinda, S.; Terao, J.; Ohigashi, H. Zerumbone, a Southeast Asian ginger sesquiterpene, markedly suppresses free radical generation, proinflammatory protein production, and cancer cell proliferation accompanied by apoptosis: The $\alpha, \beta$-unsaturated carbonyl group is a prerequisite. Carcinogenesis 2002, 23, 795-802. [CrossRef]

34. Nakamura, Y.; Yoshida, C.; Murakami, A.; Ohigashi, H.; Osawa, T.; Uchida, K. Zerumbone, a tropical ginger sesquiterpene, activates phase II drug metabolizing enzymes. FEBS Lett. 2004, 572, 245-250. [CrossRef] [PubMed]

35. Nathaniel, C.; Elaine-Lee, Y.L.; Yee, B.C.; How, C.W.; Yim, H.S.; Rasadee, A.; Ng, H.S. Zerumbone-loaded nanostructured lipid carrier induces apoptosis in human colorectal adenocarcinoma (Caco-2) cell line. Nanosci. Nanotechnol. Lett. 2016, 8, 294-302. [CrossRef]

36. Rahman, H.S.; Rasedee, A.; How, C.W.; Abdul, A.B.; Zeenathul, N.A.; Othman, H.H.; Saeed, M.I.; Yeap, S.K. Zerumbone-loaded nanostructured lipid carriers: Preparation, characterization, and antileukemic effect. Int. J. Nanomed. 2013, 8, 2769. [CrossRef] [PubMed]

37. Rahman, H.S.; Rasedee, A.; Othman, H.H.; Chartrand, M.S.; Namvar, F.; Yeap, S.K.; Abdul Samad, N.; Andas, R.J.; Muhammad Nadzri, N.; Anasamy, T. Acute toxicity study of zerumbone-loaded nanostructured lipid carrier on BALB/c mice model. BioMed Res. Int. 2014, 2014. [CrossRef] [PubMed]

38. Tan, J.W.; Israf, D.A.; Tham, C.L. Major bioactive compounds in essential oils extracted from the rhizomes of Zingiber zerumbet (L) Smith: A mini-review on the anti-allergic and immunomodulatory properties. Front. Pharmacol. 2018, 9, 652. [CrossRef] 
39. Chakraborty, A.; Coffman, R.; Jorvig, J. Zerumbone, a phytochemical from Asian ginger is a novel inhibitor of Jak2/Stat3 inhibits promigratory gene expression, growth and migration of pancreatic cancer cells. Pancreatology 2013, 2, e18-e19. [CrossRef]

40. Sidahmed, H.M.A.; Hashim, N.M.; Abdulla, M.A.; Ali, H.M.; Mohan, S.; Abdelwahab, S.I.; Taha, M.M.E.; Fai, L.M.; Vadivelu, J. Antisecretory, gastroprotective, antioxidant and anti-helicobcter pylori activity of zerumbone from Zingiber Zerumbet (L.) Smith. PLoS ONE 2015, 10, e0121060. [CrossRef]

41. Abdul, A.B.; Abdelwahab, S.I.; Al-Zubairi, A.S.; Elhassan, M.M.; Murali, S.M. Anticancer and antimicrobial activities of zerumbone from. Int. J. Pharmacol. 2008, 4, 301-304. [CrossRef]

42. Sulaiman, M.; Perimal, E.; Zakaria, Z.; Mokhtar, F.; Akhtar, M.; Lajis, N.; Israf, D. Preliminary analysis of the antinociceptive activity of zerumbone. Fitoterapia 2009, 80, 230-232. [CrossRef] [PubMed]

43. Fakurazi, S.; Hairuszah, I.; Lip, J.M.; Shanthi, G.; Nanthini, U.; Shamima, A.; Roslida, H.; Tan, Y. Hepatoprotective action of zerumbone against paracetamol induced hepatotoxicity. J. Med. Sci. 2009, 9, 161-164. [CrossRef]

44. Keong, Y.S.; Alitheen, N.B.; Mustafa, S.; Aziz, S.A.; Rahman, M.A.; Ali, A.M. Immunomodulatory effects of zerumbone isolated from roots of Zingiber zerumbet. Pak. J. Pharm. Sci. 2010, 23, 75-82. [PubMed]

45. Murakami, A.; Miyamoto, M.; Ohigashi, H. Zerumbone, an anti-inflammatory phytochemical, induces expression of proinflammatory cytokine genes in human colon adenocarcinoma cell lines. Biofactors 2004, 21, 95-101. [CrossRef]

46. Murakami, A.; Hayashi, R.; Takana, T.; Kwon, K.H.; Ohigashi, H.; Safitri, R. Suppression of dextran sodium sulfate-induced colitis in mice by zerumbone, a subtropical ginger sesquiterpene, and nimesulide: Separately and in combination. Biochem. Pharmacol. 2003, 66, 1253-1261. [CrossRef]

47. Albaayit, S.F.A.; Rasedee, A.; Abdullah, N. Zerumbone-loaded nanostructured lipid carrier gel facilitates wound healing in rats. Rev. Bras. De Farmacogn. 2020, 30, 272-278. [CrossRef]

48. Md, S.; Kit, B.; Jagdish, S.; David, D.J.; Pandey, M.; Chatterjee, L.A. Development and in vitro evaluation of a zerumbone loaded nanosuspension drug delivery system. Crystals 2018, 8, 286. [CrossRef]

49. Singh, Y.P.; Girisa, S.; Banik, K.; Ghosh, S.; Swathi, P.; Deka, M.; Padmavathi, G.; Kotoky, J.; Sethi, G.; Fan, L. Potential application of zerumbone in the prevention and therapy of chronic human diseases. J. Funct. Foods 2019, 53, 248-258. [CrossRef]

50. Dev, S. Studies in sesquiterpenes-XVI: Zerumbone, a monocyclic sesquiterpene ketone. Tetrahedron 1960, 8, 171-180. [CrossRef]

51. Damodaran, N.; Dev, S. Stereochemistry of zerumbone. Tetrahedron Lett. 1965, 6, 1977-1981. [CrossRef]

52. Dev, S.; Anderson, J.E.; Cormier, V.; Damodaran, N.; Roberts, J.D. Nuclear magnetic resonance spectroscopy. The conformational mobility of humulene and zerumbone. J. Am. Chem. Soc. 1968, 90, 1246-1248. [CrossRef]

53. Hall, S.; Nimgirawath, S.; Raston, C.; Sittatrakul, A.; Thadaniti, S.; Thirasasana, N.; White, A. Crystal structure of zerumbone [(E, E, E)-2, 6, 9, 9-Tetramethylcycloundeca-2, 6, 10-trien-1-one]. Aust. J. Chem. 1981, 34, 2243-2247. [CrossRef]

54. Kitayama, T.; Yokoi, T.; Kawai, Y.; Hill, R.K.; Morita, M.; Okamoto, T.; Yamamoto, Y.; Fokin, V.V.; Sharpless, K.B.; Sawada, S. The chemistry of zerumbone. Part 5: Structural transformation of the dimethylamine derivatives. Tetrahedron 2003, 59, 4857-4866. [CrossRef]

55. Kitayama, T.; Okamoto, T.; Hill, R.K.; Kawai, Y.; Takahashi, S.; Yonemori, S.; Yamamoto, Y.; Ohe, K.; Uemura, S.; Sawada, S. Chemistry of zerumbone. 1. Simplified isolation, conjugate addition reactions, and a unique ring contracting transannular reaction of its dibromide. J. Org. Chem. 1999, 64, 2667-2672. [CrossRef] [PubMed]

56. Rahman, H.S.; Rasedee, A.; Yeap, S.K.; Othman, H.H.; Chartrand, M.S.; Namvar, F.; Abdul, A.B.; How, C.W. Biomedical properties of a natural dietary plant metabolite, zerumbone, in cancer therapy and chemoprevention trials. BioMed Res. Int. 2014, 2014. [CrossRef]

57. Baby, S.; Dan, M.; Thaha, A.R.; Johnson, A.J.; Kurup, R.; Balakrishnapillai, P.; Lim, C.K. High content of zerumbone in volatile oils of Zingiber zerumbet from southern India and Malaysia. Flavour Fragr. J. 2009, 24, 301-308. [CrossRef]

58. Kitayama, T. Attractive reactivity of a natural product, zerumbone. Biosci. Biotechnol. Biochem. 2011, 1101072348. [CrossRef]

59. Al-Zubairi, A.S.; Abdul, A.B.; Yousif, M.; Abdelwahab, S.I.; Elhassan, M.M.; Mohan, S. In vivo and in vitro genotoxic effects of zerumbone. Caryologia 2010, 63, 11-17. [CrossRef] 
60. Eid, E.E.; Abdul, A.B.; Suliman, F.E.O.; Sukari, M.A.; Rasedee, A.; Fatah, S.S. Characterization of the inclusion complex of zerumbone with hydroxypropyl- $\beta$-cyclodextrin. Carbohydr. Polym. 2011, 83, 1707-1714. [CrossRef]

61. Junghanns, J.-U.A.; Müller, R.H. Nanocrystal technology, drug delivery and clinical applications. Int. J. Nanomed. 2008, 3, 295.

62. Bhatt, D.A.; Pethe, A. Lipid technology-A promising drug delivery system for poorly water soluble drugs. Int. J. Pharma Res. 2010. Available online: https://www.researchgate.net/publication/228467810_ Lipid_technology-A_promising_drug_delivery_system_for_poorly_water_soluble_drugs (accessed on 20 June 2020).

63. Pardeike, J.; Hommoss, A.; Müller, R.H. Lipid nanoparticles (SLN, NLC) in cosmetic and pharmaceutical dermal products. Int. J. Pharm. 2009, 366, 170-184. [CrossRef]

64. Khan, A.R.; Forgo, P.; Stine, K.J.; D'Souza, V.T. Methods for selective modifications of cyclodextrins. Chem. Rev. 1998, 98, 1977-1996. [CrossRef]

65. Atwood, J.L. Comprehensive Supramolecular Chemistry II; Elsevier: Amsterdam, The Netherlands, 2017.

66. Szejtli, J. Introduction and general overview of cyclodextrin chemistry. Chem. Rev. 1998, 98, 1743-1754. [CrossRef]

67. Gould, S.; Scott, R.C. 2-Hydroxypropyl- $\beta$-cyclodextrin (HP- $\beta-C D)$ : A toxicology review. Food Chem. Toxicol. 2005, 43, 1451-1459. [CrossRef]

68. Granero, G.E.; Maitre, M.M.; Garnero, C.; Longhi, M.R. Synthesis, characterization and in vitro release studies of a new acetazolamide-HP- $\beta$-CD-TEA inclusion complex. Eur. J. Med. Chem. 2008, 43, 464-470. [CrossRef]

69. Rabinow, B.E. Nanosuspensions in drug delivery. Nat. Rev. Drug Discov. 2004, 3, 785-796. [CrossRef] [PubMed]

70. Yadollahi, R.; Vasilev, K.; Simovic, S. Nanosuspension technologies for delivery of poorly soluble drugs. J. Nanomater. 2015, 2015. [CrossRef]

71. Shegokar, R.; Müller, R.H. Nanocrystals: Industrially feasible multifunctional formulation technology for poorly soluble actives. Int. J. Pharm. 2010, 399, 129-139. [CrossRef] [PubMed]

72. Liversidge, G.G.; Cundy, K.C. Particle size reduction for improvement of oral bioavailability of hydrophobic drugs: I. Absolute oral bioavailability of nanocrystalline danazol in beagle dogs. Int. J. Pharm. 1995, 125, 91-97. [CrossRef]

73. Mu, R.H. Manufacturing of nanoparticles by milling and homogenization techniques. In Nanoparticle Technology for Drug Delivery; CRC Press: Boca Raton, FL, USA, 2006; pp. 45-76.

74. Eid, E.E.; Bustamam Abdul, A.; Rasedee, A.; Suliman, F.E.O.; Sukari, M.A.; Fatah, S.A. Liquid chromatography-tandem mass spectroscopic method for the determination of zerumbone in human plasma and its application to pharmacokinetics. J. Mass Spectrom. 2011, 46, 772-781. [CrossRef] [PubMed]

Publisher's Note: MDPI stays neutral with regard to jurisdictional claims in published maps and institutional affiliations.

(C) 2020 by the authors. Licensee MDPI, Basel, Switzerland. This article is an open access article distributed under the terms and conditions of the Creative Commons Attribution (CC BY) license (http://creativecommons.org/licenses/by/4.0/). 